\title{
The 1807 edition of The Book of the Duchess ${ }^{1}$
}

\author{
Simone Celine Marshall
}

\begin{abstract}
This article presents a textual analysis of Geoffrey Chaucer's The Book of the Duchess, from the 1807 edition of The Poetical Works of Geoffrey Chaucer. The anonymous editor has attempted to present an edition of the text that is an improvement on all previous editions, in terms of quality and the selection of texts. The extent to which this has been achieved is difficult to determine, however. The editor is strongly influenced by Thomas Tyrwhitt's edition of The Canterbury Tales, but the care and intellect behind Tyrwhitt's edition is not found to the same degree in the 1807 edition.
\end{abstract}

\section{Introduction}

The following article is a textual analysis of some of the most striking features to have emerged thus far from an analysis of the 1807 edition of The Book of the Duchess, as compared with its predecessors (CHAUCER 1807, 115-60). The 1807 edition of The Poetical Works of Geoffrey Chaucer, in which The Book of the Duchess occurs, has only come to light in recent years, and it is yet to be determined the extent to which it differs from other editions of Chaucer's works (Marshall 2011, 118-22, MARshall 2011a, 183-86). The Book of the Duchess has been chosen as a sample text to begin this consideration, primarily because it is of sufficient scope to offer, on the one hand, a substantial enough sample from which to draw conclusions, and, on the other hand, limited enough to be manageable. In addition to these particular reasons, The Book of the Duchess is a poem the authority of which has never been questioned (WILCOCKson 1987, 966),

1. I wish to acknowledge the generous assistance of the University of Otago Research Grant that allowed me the time for the research and writing of this article. I would also like to acknowledge the meticulous work of my research assistant, Dr Carol Wyvil. 
and thus it has appeared in every printed edition of the works of Chaucer, providing this study with extensive points for comparison. ${ }^{2}$

The 124-volume edition of The Poets of Great Britain, containing The Poetical Works of Geoffrey Chaucer, came into being when, in 1807, a group of thirty-three London booksellers began publication of a work that claims, from its title page, to be a reprint of John Bell's 1782 series The Poets of Great Britain. ${ }^{3}$ The more popular poets within the 1782 series had been reprinted from time to time during the twenty or so years after its initial publication, notably the works of John Dryden was reprinted twice, and thus, in 1807, it

2. The Book of the Duchess appears in the following publications up until the end of the nineteenth century: William Thynne, ed. 1532. The Workes of Geoffrey Chaucer newly printed, with dyuers workes whiche were neuer in print before. London: Thomas Godfray. repr. 1542, and ca. 1550. STC 5068, 5069, 5070, 5071, 5072, 5073, 5074; John Stow, ed. 1561. The Woorkes of Geffrey Chaucer newlie printed, with diuers addicions, which were never in printed before London: John Kyngston. STC 5075, 5076, 5076.3; Thomas Speght, ed. 1598. The Works of Our Ancient, Learned, Excellent English Poet, Jeffrey Chaucer: As they have lately been compar'd with the best manuscripts, and several things added, never before in print. London: George Bishop. repr. 1602 and 1687. STC 5077, 5078, 5079, 5080, 5081, Wing C3736; John Urry, ed. 1721. The Works of Geoffrey Chaucer, Compared with the Former Editions, and Many valuable MSS, out of which, Three Tales are added which were never before printed. London: Bernard Lintot. STC T106027; John Bell, ed. 1783. The Poetical Works of Geoffrey Chaucer. Edinburgh: Apollo. STC T75497; Robert Anderson, ed. 1792. A Complete Edition of the Poets of Great Britain. London: John and Arthur Arch; Geoffrey Chaucer. 1807. The Poetical Works of Geoffrey Chaucer. London: Cadell, Davies, et al.; Alexander Chalmers, ed. 1810. Works of the English Poets, from Chaucer to Cowper. London: J. Johnson; Geoffrey Chaucer. 1822. The Poems of Geoffrey Chaucer. 5 Vols. Chiswick: C. Whittingham; Frederick J. Furnivall, ed. 1868-80. Odd Texts of Chaucer's Minor Poems. Chaucer Society 23. London: Oxford University Press; Frederick J. Furnivall, ed. 1871-79. A Parallel-Text Edition of Chaucer's Minor Poems. Chaucer Society 21. London: Paul, Trench, and Trubner; Walter W. Skeat, ed. The Complete Works of Geoffrey Chaucer. Oxford: Clarendon Press.

3. John Bell, ed. 1783. The Poets of Great Britain Complete from Chaucer to Churchill. Edinburgh: Apollo. The full list of booksellers is as follows: Cadell and Davies; Longman, Hurst, Rees, and Orme; Nichols and Son; J. Walker; Wilkie and Robinson; W. J. and J. Richardson; F. C. and J. Rivington; Lackington, Allen, and Co.; R. H. Evans; Cuthell and Martin; Scratcherd and Letterman; Otridge and Son; Vernor, Hood, and Sharpe; R. Faulder; T. Payne; J. Nunn; R. Lea; J. Deighton; J. Johnson; W. Clarke and Sons; W. Lowndes; J. Hatchard; Black and Parry; J. Harding; E. Jeffrey; J. Carpenter; W. Miller; Leigh and Sotherby; Payne and Mackinlay; Mathews and Leigh; P. Wynne; J. Booker; and Samuel Bagster. 
must have seemed a financially safe venture to reproduce the entire series. Volumes one to fourteen (or one to seven, as it was also bound) comprise The Poetical Works of Geoffrey Chaucer. ${ }^{4}$ Eleanor Prescott Hammond notes the edition as a reprint of Bell (Hammond 1908, 132), while Caroline Spurgeon indicates she was not able to find a copy of this work. She says: "No copy of this has been found in a public library, nor is it mentioned by Miss Hammond in Chaucer: A Bibliographical Manual. The title is taken from a dealer's list" (SPurgeon 1914-25, 29). According to the work's title page, Hammond has described the work correctly: it does indeed claim to be a reprint of Bell's 1782 edition. The reality, however, is somewhat different. The identity of the editor of this edition is unknown, but he has provided an extensive introduction to the edition outlining his procedure. Here it becomes clear that the work is rather more than a reprint of Bell, in fact the works of Chaucer have been markedly revised and re-edited. ${ }^{5}$

While Hammond's and Spurgeon's descriptions of the edition indicate why this edition has been overlooked by modern scholars, it is curious to note that the edition does not seem to have attracted any attention at the time of its publication. As we will see, other nineteenth-century editors of Chaucer never refer to it, nor do their editions suggest they had seen it. Furthermore, no mention is made of the edition in the period's literary magazines.

\section{The editorial assertions of the 1807 edition}

The editor of the 1807 edition begins with a General Advertisement, which is divided into two sections, one entitled The Canterbury Tales and the other The Disputed Tales and Miscellaneous Poems. The division here is important, as it reflects the distinction made by earlier editors, most nota-

4. Geoffrey Chaucer. 1807. The Poetical Works of Geoffrey Chaucer. London: Cadell, Davies, et al. According to Thomas Bonnell: "To save customers money on binding, they marketed the set in two forms, taking the trouble to print different series title-pages listing different contents, one headed The Poets of Great Britain, in One Hundred and Twenty-Four Volumes, the other The Poets of Great Britain, in Sixty-One Double Volumes". See Thomas Bonnell. 2008. The Most Disreputable Trade. Oxford: Oxford University Press. 293-94.

5. The 1807 series included fifty-four poets in total; three from Bell's series were removed, while seven new poets were added to the series. I have not attempted to investigate whether the works of other poets within the series were similarly re-edited for the 1807 printing. 
bly John Bell and Robert Anderson (Bell 1782-83; Anderson 1792). Both Bell's and Anderson's editions had used (without permission) Thomas Tyrwhitt's first edition of The Canterbury Tales, while using John Urry's 1721 edition of Chaucer's works for the remainder of the poems. ${ }^{6}$ Thus the 1807 editor's distinction is a clear indication that he, too, is in some way conceiving of his enterprise in relation to the efforts of his predecessors.

It is beneficial, for accuracy's sake, to quote extensively from the Advertisement. Of The Canterbury Tales, the editor says:

The Canterbury Tales are printed from the second edition of Mr. Tyrwhitt's publication, [2 vols. 4to, 1798]. In conformity with Mr Tyrwhitt's evident intentions, the present Editor has introduced in the places to which they belong, several important revisions, by that learned critic of his own notes and opinions; the following Abstract from the Advertisement prefixed by the delegates of Clarendon Press, tends to explain what the revisions are:

"In a copy of the work, which Mr. Tyrwhitt had reserved for his own use, it was found that he had inserted several emendations and additions; in parts of the work having written some things otherwise than as he first gave them to the world.

It is according to such corrections, therefore, that the work is now printed..."

Still, however, in the edition from the Clarendon press, the principle of incorporation does not seem to have been carried so far as is desirable and as useful attention to method may safely urge it; for the more deliberate opinions of the learned Editor are left in the promiscu-

6. Thomas Tyrwhitt was most aggrieved by Bell's actions in particular: "The Assured manner in which my name is used, may lead people to imagine that I have been at least consenting to this republication of my book; and therefore I beg the favour of you, and all my other friends, to take every opportunity (the more public the better) of declaring for me, that the whole transaction has passed without my consent, approbation, or knowledge". See Thomas Tyrwhitt. 1783. Gentleman's Magazine 53.1: 461-62. See also Thomas Tyrwhitt, ed. 1778. The Canterbury Tales of Chaucer, to which are added, an essay upon his language and versification; an introductory discourse; and notes. first edition. London: Thomas Payne. STC T76319, and John Urry, ed. 1721. The Works of Geoffrey Chaucer, Compared with the Former Editions, and Many valuable MSS, out of which, Three Tales are added which were never before printed. London: Bernard Lintot. STC T106027. 
ous places where they happened to be penned. It appeared, therefore, to the present Editor, that he should essentially promote the design of $\mathrm{Mr}$ Tyrwhitt ... The present Editor has, therefore, altered every retracted or connected passage, making it correspond with the opinion subsequently pronounced by Mr Tyrwhitt. (CHAUCER 1807, ix-xi)

The editor, then, has apparently expanded on the work of the editors of the second edition of Tyrwhitt's The Canterbury Tales, thus completing the work that Tyrwhitt himself would have done, had he lived long enough to do so.

Following this, the editor then introduces his approach to editing the remaining texts in the edition, under the title of The Disputed Tales and Miscellaneous Poems:

The Edition in 1721, by Mr. Urry, has been hitherto the best, of that part of the works ascribed to Chaucer to which the late able Editor of the Tales did not extend his labours: but the blemishes imputed to the edition of 1721, are considerable.

Mr. Tyrwhitt, Mr. Todd, and other competent critics, have concurred with Dr. Hickes in the censure (Sax. Gram. P. 29.) of Mr. Urry, for changing the old English hir into their, and hem into them, without the authority of a single manuscript. The words so unwarrantably supplanted have been restored in this edition.

Mr. Urry has been further blamed (Tyrwhitt's Essay, n. 68,) for spelling nouns plural as dremis, rockis; whenever he wished to denote that, to complete the metre, the word must be pronounced with a factitious syllable; he followed a similar practice in the termination of the preterite of verbs, transforming lived, limped, to livid, limpid. This mechanical mode of indicating an extra syllable disguises the meaning of the word, and misrepresents the state of English orthography, when Chaucer wrote; it is therefore, in the present impression, discarded as an unjustifiable innovation.

Another approximation to the manuscripts has been made, by rescinding the sign (') of the genitive case, and by restoring the spelling where es has been without authority converted into is.

In many words diversely spelt, the Editor has followed the orthography of Tyrwhitt, to prevent the multiplication of articles in the Glossary.

The punctuation has been throughout revised. Chaucer was aware that the power of punctuation, as differently exercised, may often occasion or supersede a commentary. (CHAUCER 1807, xii-xiii) 
It would seem, therefore, that the 1807 editor has used John Urry's 1721 edition as a base text for the remainder of the texts in his edition. The editor, noting the criticism of others, has also acknowledged the apparent errors within Urry's edition, which will apparently be corrected in his own edition. It is perhaps pertinent to consider briefly the particular features of Urry's edition, in order to reconcile the 1807 editor's apparent need to avoid Urry's errors.

The 1721 edition of John Urry has been much maligned over the centuries, and for many different reasons, but as William Alderson points out, it is an edition that has much to recommend it, and, even acknowledging its failings, one must accept that it is an edition that continued to have a great deal of influence in the eighteenth and nineteenth centuries (Alderson 1984, 114). Problems arose with the edition during the process of its creation with the sudden death of John Urry in 1715, long before the work was near completion. The friends and associates who then took up the work and brought it to completion seem to have done so grudgingly, and clearly there was a great deal of frustration at the state in which Urry had left his work. ${ }^{7}$ The biggest difficulty was that Urry had not left any documentation indicating his editorial methods, and so those continuing the work were left to guess at his intentions. From the information Urry did leave, it is clear that he had intended to consult as many manuscripts as possible to use for comparison for his edition, and he even left a list of those he did consult. It is not clear, however, how he intended to use the manuscripts, and the resulting texts do not show many instances of influence from manuscript readings.

Perhaps one of the biggest failings of Urry's edition, however, was his method of emending the text. There was, without doubt, a logic behind his process, but he left no explanations for this. It seems that Urry supposed that Chaucer's metre must surely have been regular, and thus any irregularities must have been the result of poor work from scribes and/or previous editors. As such, Urry undertook to 'correct' the metrical errors by a series of different means. It is this act primarily that led to numerous negative charges against the edition. Thomas Tyrwhitt infamously described Urry's edition as "by far the worst that was ever published" (TYRwhitt 1798, lxiii).

7. Anthony Wood. 1691-92. Athenae Oxonienses: The History of the Writers of the University of Oxford, from the Year of our Lord 1500 to the end of 1640. London: Thomas Bennet. 
There are four particular features to Urry's method of editing. The first is Urry's habit of including a grave accent "to distinguish those medial or final -e's which should be pronounced in a Chaucerian line" (AldDerson 1984, 110). Urry was convinced the Chaucer, as a great poet, must have used a regular metre in his verse, and thus whenever he encountered lines that did not agree with this pattern, Urry would insert whatever was required to 'correct' the metre. Frequently this amounted to a grave accent on an e, although he employed other methods as well. The second feature of Urry's method is to alter the spelling of words ending with -en, -ed, -es, -est, and -eth, to -in, -id, -is, -ist, and -ith whenever he considered such words require a more strongly pronounced syllable. Third, Urry at times has added entire prefixes and suffixes in order to complete the metre. As Alderson says, Urry seems to have regarded these "as free counters in his metrical game" (1984, 110). Finally, Urry at times has added or omitted whole words, again in order ensure the metre complies.

It is interesting to note, then, that many of the 1807 editor's proposed emendations do accurately pinpoint the errors in Urry's text. However it is not clear how the editor will judge when supposed errors are to be corrected, or to what extent he is using earlier editions or manuscripts to help guide him. There are, too, instances where the editor is clearly intending to make corrections under the guise of correcting Urry's errors where it is not certain there are errors existing. For instance, he states that he will regularise the spelling and introduce punctuation. He not does state categorically that these are among Urry's errors, but there is an implicit assumption that this is the case. Most notable, it seems to me, is that the editor rather elides the extent to which he intends to refer to manuscript sources.

\section{Contents of the 1807 edition}

The results of this investigation thus far have proven to be rather more idiomatic than expected. One significant feature of The Book of the Duchess as it appears in the 1807 edition is found in a footnote at the beginning of the text:

This Poem, which in the editions is called the Dreme of Chaucer-a title calculated to confound it with Chaucers Dreme, is in the Leg. Of G. W. 418. denominated by our Poet, the Deth of Blaunche the Duchess. In the MSS. Fairf. 16, and Bod. 638, it is called 'the Booke of the Duchesse.' (Chaucer 1807, 115) 
Here we learn that the editor did indeed refer to at least these two manuscripts when preparing the text of The Book of the Duchess, and thus, despite his rather vague attitude towards the manuscripts as stated in the introduction, it appears he did indeed have some access to them.

It is certain, at the very least, that despite being aware of at least two of the three fifteenth-century manuscripts in which the poem occurs, he made no obvious use of them, aside from the use of the title to the poem. ${ }^{8}$ This in itself is worthy of some comment. Steve Ellis, in his article, remarks that the first published use of The Book of the Duchess as the poem's title, is in the Chiswick 1822 edition of the poem (Chaucer 1822). Prior to this, according to Ellis, it was known as Chaucer's Dream or The Dream of Chaucer (Ellis 1995, 249-58). This title caused considerable confusion among early editors as another poem, today entitled The Isle of Ladies and not thought to be authored by Chaucer at all, was also known by this title, and certainly editors did confuse them on occasion (FARBER 2008, 207-25). Here, then, we have a clear example of the work being published under the title of The Book of the Duchess as early as 1807.

As already noted, from the footnote at the start of the text, we learn that, at the very least the editor was aware of and had seen the Fairfax and Bodley manuscripts in which the poem occurs. While conjecture, it seems quite probable that he was unaware of the Oxford, Bodleian Library, MS Tanner 346 manuscript, despite all three being housed at the Bodleian Library at Oxford, as one would have thought it likely he would have mentioned it here, even to note that its title, differing from the others, is written as Chaucer's Dream.

A line-by-line comparison with each of the three manuscript editions of the poem, as well as with the printed editions of William Thynne (1532, 1542, and c.1550), John Stow (1561), Thomas Speght (1598, 1602, and 1687), John Urry (1721), John Bell (1782), Robert Anderson (1798), and Alexander Chalmers (1810), indicates that the 1807 editor has indeed used Urry's text as a base text for his edition, and then made copious editorial changes to versification and orthography throughout. ${ }^{9}$

8. The Book of the Duchess appears in Oxford. Bodleian Library. MS Fairfax 16, Oxford. Bodleian Library. MS Bodley 638, and Oxford. Bodleian Library. Tanner 346.

9. For a consideration of each of these editions of the works of Chaucer, see Blodgett 1979; Blodgett 1984; Costomiris 2003; Donaghey 1997; Fletcher 1978; Gadd and Gillespie 2004; Hetherington 1964; PearsAll 2004; and BonNell 1987. 
Perhaps the most notable change that the 1807 editor has made throughout his text is to remove the -in, -id, -is, -ist, and -ith endings that Urry had first inserted (and which Bell retained) into the text. Just as he had claimed in his introduction, he has changed these word endings to -en, -ed, -es, -est, and -eth throughout. It might be assumed, therefore, that the editor is attempting to remove Urry's errors and to revert back to the features of the manuscript editions of the poem, or at the very least to Thynne's 1532 edition, but this is not the case at all. There are a total of 513 instances where the 1807 editor alters a word from Urry's text ending with -in, -id, -is, -ist, or -ith to ending with -en, -ed, -es, -est, or -eth, the most substantial change to the entire text, but this rarely agrees with any one of the three manuscripts or with Thynne's edition. What is noticeable here is that the instances that do agree are examples such as the words 'other' (changed from 'othir'), 'ever' (changed from 'evir'), and 'wonder' (changed from 'wondir'). The instances where the 1807 text does not agree with the manuscript or with Thynne's edition are words such as 'withouten' (changed from 'withoutin'), which occurs in the manuscripts and in Thynne as 'withoute', 'slepen' (changed from 'slepin'), which occurs as 'slepe', and 'asken' (changed from 'askin'), which occurs as 'aske'. Thus we can see the trend is that Urry has added '-in' to words that originally had an '-e' ending, and so it is clear the 1807 editor has not consulted the manuscripts or Thynne, but, on all 513 instances, has simply altered his text to agree with the general criticism as noted by Tyrwhitt and other critics.

Altering the text to agree with Tyrwhitt's logic appears to be a feature of the 1807 editor. It seems to me that even if he was aware of and had access to the manuscripts (as he appears to have done for two of those containing The Book of the Duchess), he has not used the manuscripts' orthography, preferring instead to rely on other critics' views of the text (HiCKes 1705). And, if one considers how the editor explains his concerns about Urry's use of the -in, -id, -is, -ist, and -ith endings, in fact his argument is sound:

This mechanical mode of indicating an extra syllable disguises the meaning of the word, and misrepresents the state of English orthography, when Chaucer wrote; it is therefore, in the present impression, discarded as an unjustifiable innovation. (CH AUCER 1807, xii)

As the editor explains, Urry's intention behind altering the text to use these endings is to outline clearly to the reader (especially one not familiar with Middle English, as was often the case by the eighteenth century) that some syllables were to be pronounced, in order for the line of verse to agree with the poem's metre (Lerer 1993; Matthews 1999; Morse 
2003; Prendergast 2003). The editor admits this as an 'innovation' to the text, and in itself does not disapprove. His concern is that the reader may inadvertently introduce other incorrect assumptions about the text so written, such as to assume that this spelling is an accurate indication of orthography as used by Chaucer, and that the reader further misunderstand the meaning of these altered words. The editor's concern seems understandable, and his method of correction has been thorough. The difficulty for a modern editor, however, is that editor's changes have no provenance in the manuscripts.

The 1807 editor also criticizes Urry's edition for its odd use of personal pronouns. All three of the fifteenth-century manuscripts tend to use 'hir' as the third-person feminine objective pronoun. In the 1532 Thynne edition the pronoun is spelt 'her', and in the Urry edition the pronoun is also spelt 'her', on a total of 112 occasions. The 1807 editor has consistently emended this pronoun to 'hire', despite this spelling appearing in no other earlier edition or manuscript. In addition, Urry has consistently used the third person possessive pronoun spelt 'ther', when it appears in all of the manuscripts and in Thynne spelt 'her'. In the 1807 edition, the word is spelt 'hir' throughout. It seems difficult to understand the 1807 editor's reasoning for his emendations of these pronouns, as they clearly show no resemblance to earlier editions or manuscripts (Burrow And Turville-Peter 2005; Mitchell and Robinson 2005). I would suggest that this is an instance of the editor following the orthography outlined by Tyrwhitt in the glossary to his edition of The Canterbury Tales. In his glossary, Tyrwhitt has the following entries:

HIR, pron. Poss. SAX. Their.

HIRE, pron. Poss. SAX. Her. (Tyrwhitt 1798, 582)

This agrees completely with what the 1807 editor has used in his text, and it seems very likely that Tyrwhitt's glossary is the origin of this emendation. Interestingly, Tyrwhitt's glossary in his second edition acknowledges Urry's glossary as being well crafted, and in fact goes so far to indicate that it was the basis for Tyrwhitt's own glossary:

It would be injustice to the learned author of the Glossary to Mr. Urry's edition, not to acknowledge, that I have built upon his foundations, and often with his materials. (TyRwhitT 1798, 521)

Despite this, Tyrwhitt concludes by stating that "Mr. Urry's edition should never be opened by any one for the purpose of reading Chaucer" (TYR- 
whit 1798 , 524). Perhaps with such attitudes, it is not surprising that the 1807 editor chose to follow Tyrwhitt's orthography.

Further in agreement with Tyrwhitt, it seems likely that the 1807 editor has elected to use the spellings of 'hire' for 'her' and 'hir' for 'their' in accordance with Tyrwhitt's explanation of Chaucer's use of these words in The Canterbury Tales:

\begin{abstract}
Hir; Their. The Possessive Pronoun of the third Person Plural is variously written, Hir, Hire, Her, and Here; not only in different Mss. But even in the same page of good Mss. There seems to be no reason for perpetuating varieties of this kind, which can only have taken their rise from the unsettled state of our Orthography before the invention of Printing, and which now contribute more than any real alteration of the language to obscure the sense of our old Authors. In this edition therefore, Hir is constantly put to signify Their; and Hire to signify Her, whether it be the Oblique case of the Plural Pronoun She, or the Possessive of the same Pronoun. (Tyrwhitt 1798, 64-65)
\end{abstract}

This note is made specifically in regard to Tyrwhitt's grammatical analysis of the first eighteen lines of The Canterbury Tales. The 1807 editor had noted with regard to his edition of The Canterbury Tales that he would "promote the design of Mr. Tyrwhitt" (CHAucer 1807, xi), and it would seem that this has followed through into the other texts within his edition. As the note above explains, Tyrwhitt has made a decision about which spelling to use for these particular pronouns, and has used them consistently throughout. The 1807 editor, it would seem, has done the same, regardless of the spelling used in any of the earlier editions of The Book of the Duchess.

The use of the apostrophe is a notable feature of Urry's text that had not been used in previous editions and which does not occur in the manuscripts containing Chaucer's works. In his introduction, the 1807 editor complained about Urry's use of this piece of punctuation and indicated his method of correction:

Another approximation to the manuscripts has been made, by rescinding the sign (') of the genitive case, and by restoring the spelling where es has been without authority converted into is. (CHAUCER 1807 xii)

In The Book of the Duchess, there are eleven such instances in Urry's text where the genitive case has been represented by an apostrophe, and on each occasion the 1807 editor has emended these in the manner he has 
indicated above. For instance, Urry's text has 'slep'is', 'bedd'is', and 'world'is', and this is emended in the 1807 edition to 'slepes', 'beddes', and 'worldes'. The editor has suggested that this emendation is an 'approximation to the manuscripts', which, broadly speaking, is correct. On this particular point, the three manuscripts rarely agree with each other, but frequently they will reflect a spelling that is either the same or similar to that chosen by the 1807 editor. Interestingly, however, on every occasion, the 1807 text agrees with Thynne's 1532 edition. In the case of the examples given above, the manuscripts present the following:

$\begin{array}{lllllll}\text { Line } & \text { 1807 edition } & \text { MS Tanner 346 } & \text { MS Bodley 638 } & \text { MS Fairfax 16 } & \text { Thynne 1532 } & \text { Urry 1721 } \\ 168 & \text { slepes } & \text { slep } & \text { slepes } & \text { slepes } & \text { slepes } & \text { slep'is } \\ 199 & \text { beddes } & \text { beddis } & \text { beddys } & \text { beddys } & \text { beddes } & \text { bedd'is } \\ 209 & \text { worldes } & \text { worldis } & \text { worldes } & \text { worldes } & \text { worldes } & \text { world'is }\end{array}$

Unfortunately with so few examples in total to judge, it is difficult to know if this indicates that the 1807 editor was using Thynne's text for these emendations, some other model, or that this agreement is entirely coincidental.

The use of apostrophes is, however, an interesting and unusual feature of Urry's text. While there are eleven identifiable instances, as noted above, that correspond to the 1807 editor's emendatory practice, there are in total 119 apostrophes in The Book of the Duchess. Aside from the eleven mentioned already, there are 41 instances where the apostrophe is used to indicate a contraction or abbreviation of a word, such as 'so'rowful' and 'hem'. The remaining 67 instances of apostrophes are less easy to explain, but appear to relate to Urry's method of indicating the metre of the verse.

The 1807 editor has described Urry's method of spelling as an "unjustifiable innovation". Perhaps he is being polite, but it seems to me that this statement reflects the fact the Urry's alterations to the text were, indeed, innovations intended to aid the reader otherwise unfamiliar with Middle English verse. William Alderson, too, notes that despite the severe criticisms of Urry's edition, it does indeed make a genuine effort at improving the texts of Chaucer, and its greatest weakness appears to be that Urry died before being able to leave an explanation and justification for his editorial methods (Alderson 1984, 114). Just as Urry's spelling is described as an "unjustifiable innovation", so too could one describe Urry's method of correcting and indicating metre.

It seems that Urry's use of apostrophes, when they do not correspond to either the genitive case or to contractions or abbreviations, indicates an unstressed vowel in the line of verse. For instance, "And many' an hart, and 
many' an hinde" (line 427), shows that the metre is four stressed syllables per line, and while ordinarily, Urry believes, there will be correspondingly four unstressed syllables in the line, here he is indicating that there are two extra unstressed syllables (DAvis 1987, xxix-xlv). As mentioned, this use of the apostrophe occurs on 67 occasions in The Book of the Duchess, but it is completely removed by the 1807 editor.

Urry added another feature to his text to aid the reader in the pronunciation of the Middle English. Throughout his text, he has inserted the grave accent above certain syllables in words in order to indicate to the reader that these syllables are indeed to be pronounced. This action is entirely Urry's invention and does not appear in any of the manuscripts or earlier editions, but it appears to be a feature that the 1807 editor has adopted throughout his text. Thus, despite his criticisms of Urry's text, the 1807 editor has been most happy to accept many of his innovations. As an example, in line 20, the 1807 editor has presented, in agreement with Urry, the following line: "Not longè tymè to endure", in which the two grave accents indicate that the terminal e on the words 'longe' and 'tyme' is to be pronounced, in order to agree with the four stressed line metre, and yet the terminal e on the word 'endure' remains silent.

\section{Some Conclusions and the Impact of the 1807 edition}

It is difficult to judge the impact of the 1807 edition of The Poetical Works of Geoffrey Chaucer. Unusually, there are no references to the edition during the period in which it was published in any of the literary magazines of the day..$^{10}$ Even Samuel Bagster, one of the London booksellers who funded the edition, makes no mention of the edition in his posthumously published autobiography (BAGSTER 1972). It is possible that the edition was not regarded by those with financial interests in the project as a new edition as such, but rather as a reprint of Bell's successful 1782 edition (DANE 1988, 217-36; DANE 1998). It seems likely, too, that the link with Bell's edition ensured that the edition remained largely unknown by later scholars of Chaucer.

Perhaps even more remarkable is the fact that the edition appears to have remained unknown even to other nineteenth-century editors of Chaucer's

10. This includes The Gentleman's Magazine, The Weekly Dispatch, The Edinburgh Review, The Monthly Register and Encyclopedian magazine, The Annual Review and History of Literature, The Eclectic Review, The Athenaeum, The Director, The Monthly, and The Critical Review. 
works. Alexander Chalmers' edition in 1810, just three years later, shows no resemblance to the 1807 edition, nor do other, later, nineteenth-century editions. Walter Skeat's important 1894 edition, which presented the most thorough assessment of the works of Chaucer to that point, makes no reference to it whatsoever (SKEAT 1894).

This study is clearly a preliminary work to consider only a very small portion of the 1807 edition of The Poetical Works of Geoffrey Chaucer. Future research will need to be carried out on other texts within the collection, as well as some consideration of the edition's relationship with other editions of Chaucer, and with the publishing history of the early nineteenth century. Particularly important among the questions to be considered in future research is the issue regarding the authenticity of the poems (BRUSENDORfF 1925; Boffey 1995, 37-47). Not considered in this article, the large number of poems that we today consider spurious are first removed from the Chaucer canon in the nineteenth century, fundamentally with Skeat's edition (Skeat 1894; Skeat 1897; Bradshaw 1888). The 1807 edition, however, does appear to show some inclination towards this process by relegating the spurious texts to a less prominent location in the collection, categorised under the title of Miscellaneous works often imputed to Chancer.

From this brief examination of the text of The Book of the Duchess, however, it appears to me that the 1807 editor at the very least, fully intended to present an edition of the text that was an improvement on all previous texts. The extent to which he has achieved this is less easy to determine, however. Unlike Urry's edition, we are able to determine a clear and logical editorial process throughout, thus making his decisions understandable. The editor's deference to Thomas Tyrwhitt is clear throughout, but it seems unlikely to me that we can regard the 1807 edition as the edition that Tyrwhitt himself would have produced, had he lived long enough to do so. The scrupulous care and powerful intellect behind Tyrwhitt's edition of The Canterbury Tales is not found to the same degree in the 1807 edition. What we see is a gesture towards Tyrwhitt's style, rather than an example of rigorous editing.

The 1807 editor appears well versed in the work of Tyrwhitt, and with the 1721 edition of Urry, but, despite the superficial impressions he gives, it does not appear that he has done the research that Tyrwhitt undertook in examining the manuscript editions of the poems. To be fair, this study considers only The Book of the Duchess; it is entirely possible that the editor's efforts were inconsistent across the works of Chaucer, or indeed that it is not the work of one individual. We have no sense of the time period over which the editorial work took place, and thus there is no way to estimate if 
it was feasible for a single man to conduct the editing process alone (BLAGden 1960; Brown 1982; Maxted 1977; Myers and Harris 1997). What we can determine from examining a single poem is that it is fair to consider the work a new edition, sufficiently different from all previous editions, and with some commendable effort at advancing the quality of the text.

\section{Works Cited}

\section{Manuscripts}

Oxford. Bodleian Library. MS Bodley 638

Oxford. Bodleian Library. MS Fairfax 16

Oxford. Bodleian Library. MS Tanner 346

\section{Printed Sources}

Alderson, William. 1984. "John Urry (1666-1715)". Editing Chaucer: The Great Tradition, edited by Paul G. Ruggiers, 93-115. Norman: Pilgrim Books.

Anderson, Robert, ed. 1792. A Complete Edition of the Poets of Great Britain. London: John and Arthur Arch.

Bagster, Samuel. 1972. Samuel Bagster of London 1772-1851: An Autobiography. London: Samuel Bagster and Sons.

BeLl, John, ed. 1783. The Poetical Works of Geoffrey Chaucer. Edinburgh: Apollo. STC T75497.

Benson, Larry D., ed. 1987. The Riverside Chaucer. Oxford: Oxford University Press.

Blagden, Cyprian. 1960. Stationers' Company 1403-1959. London: Allen and Unwin.

Blake, N. F. 1981. "The Textual Tradition of The Book of the Duchess". English Studies 62.3: 237-248.

Blodgett, James E. 1979. “Some Printer's Copy for William Thynne's 1532 Edition of Chaucer". The Library 1: 97-113.

Blodgett, James E. 1984. "William Thynne". Editing Chaucer: The Great Tradition, edited by Paul G. Rug giers, 35-52. Norman: Pilgrim Books.

Boffey, Julia. 1995. "Proverbial Chaucer and the Chaucer Canon". Huntington Library Quarterly 58.1: 37-47.

Bonnell, Thomas F. 1987. "John Bell's 'Poets of Great Britain': The 'Little Trifling Edition' Revisited”. Modern Philology 85.2: 128-52.

Bonnell, Thomas F. 2008. The Most Disreputable Trade: Publishing the Classics of English Poetry, 1765-1810. Oxford: Oxford University Press.

Bradshaw, Henry. 1888. Collected Papers. Cambridge: Cambridge University Press.

Brown, Phillip A. H. 1982. London Publishers and Printers 1800-1870. London: British Library. 
Brusendorff, Aage. 1925. The Chaucer Tradition. Oxford: Oxford University Press, 1925.

Burrow, J. A., and Thorlac Turville-Petre. 2005. A Book of Middle English, third edition. Oxford: Blackwells.

Chalmers, Alexander, ed. 1810. Works of the English Poets, from Chaucer to Cowper. London: J. Johnson.

Chaucer, Geoffrey. 1807. The Poetical Works of Geoffrey Chaucer. 14 Vols. London: Cadell, Davies, et al.

Chaucer, Geoffrey. 1822. The Poems of Geoffrey Chaucer. 5 Vols. Chiswick: C. Whittingham.

Costomiris, Robert. 2003. "Some New Light on the Early Career of William Thynne, Chief Clerk of the Kitchen of Henry VIII and Editor of Chaucer". The Library 4.1: 3-15.

Dane, Joseph A. 1988. "The Reception of Chaucer's Eighteenth-Century Editors". Text 4: 217-36.

Dane, Joseph A. 1998. Who is Buried in Chaucer's Tomb? Studies in the Reception of Chaucer's Book. East Lansing: Michigan State University Press.

Davis, Norman. 1987. "Language and Versification". The Riverside Chaucer, edited by Larry D. Benson, xxix-xlv. Oxford: Oxford University Press.

Donaghey, Brian. 1997. "William Thynne's Collected Edition of Chaucer: Some Bibliographical Considerations". Texts and their Contexts, edited by Julia Boffey and John Scattergood, 150-64. Dublin: Four Courts.

Ellis, Steve. 1995. "The Death of The Book of the Duchess". Chaucer Review 29.3: 249-58.

Farber, Annika. 2008. "Usurping 'Chaucers dreame': Book of the Duchess and the Apocryphal Isle of Ladies". Studies in Philology 105.2: 207-25.

Fletcher, Bradford Y. 1978. "Printer's Copy for Stow's Chaucer". Studies in Bibliography 31: 184-201.

Furnivall, F. J., ed. 1886. More Odd Texts of Chaucer's Minor Poems. Chaucer Society 77. London: Paul, Trench, and Trubner.

Furnivall, Frederick J. 1871-79. A Parallel-Text Edition of Chaucer's Minor Poems. Chaucer Society 21. London: Paul, Trench, and Trubner.

Furnivall, Frederick J., ed. 1868-80. Odd Texts of Chaucer's Minor Poems. Chaucer Society 23. London: Oxford University Press.

Gadd, Ian, and Alexandra Gillespie, eds. 2004. John Stow (1525-1605) and the Making of the English Past. London: British Library.

Gillespie, Alexandra. 2006. Print Culture and the Medieval Author: Chaucer, Lydgate, and their Books 1473-1557. Oxford: Oxford University Press.

Hammond, Eleanor Prescott. 1908. Chaucer: A Bibliographical Manual. New York: Macmillan.

Hetherington, John Rowland. 1964. Chaucer, 1532-1602: Notes and facsimile texts, designed to facilitate the identification of defective copies of the black-letter folio editions of 1532, 1542, c.1550, 1561, 1598 and 1602. Birmingham: John Hetherington. 
Нicкes, George. 1705. Linguarum vett. septentrionalium thesaurus grammatico-criticus et archæologicus. Oxford: Sheldonian Theatre.

Lerer, Seth. 1993. Chaucer and his Readers. Princeton: Princeton University Press.

Marshall, Simone Celine. 2011. "The 1807 Edition of the Poetical Works of Geoffrey Chaucer". Notes and Queries 58.2: 183-186.

Marshall, Simone Celine. 2011. The Anonymous Text: The 500-Year History of The Assembly of Ladies. Bern: Peter Lang.

Matthews, David. 1999. The Making of Middle English, 1765-1910. Minneapolis: University of Minnesota Press.

Maxted, Ian. 1977. The London Book Trades 1775-1800. Folkestone: Dawson.

Mitchell, Bruce, and Fred C. Robinson. 2005. A Guide to Old English, sixth edition. Oxford: Blackwells.

Morse, Charlotte. 2003. "Popularizing Chaucer in the Nineteenth Century". Chaucer Review 38.2: 99-125.

Myers, Robin, and Michael Harris. 1997. Stationers' Company and Book Trade. Winchester: St. Paul's Bibliographies.

Pearsall, Derek. 2004. "John Stow and Thomas Speght as Editors of Chaucer". John Stow (1525-1605) and the Making of the English Past, edited by Ian GADD and Alexandra Gillespie. London: British Library.

Реск, Russell A. 1988. Chaucer's Romaunt of the Rose and Boece, Treatise on the Astrolabe, Equatorie of the Planetis, Lost Works, and Chaucerian Apocrypha: An Annotated Bibliography. Toronto: University of Toronto Press.

Prendergast, Thomas. 2003. Chaucer's Dead Body. New York: Routledge.

Ruggiers, Paul G., ed. 1984. Editing Chaucer: The Great Tradition. Norman: Pilgrim Books.

Skeat, Walter W., ed. 1894. The Complete Works of Geoffrey Chaucer. Oxford: Clarendon Press.

Skeat, Walter W., ed. 1897. Chaucerian and Other Pieces. Oxford: Clarendon Press.

Speght, Thomas, ed. 1598. The Works of Our Ancient, Learned, Excellent English Poet, Jeffrey Chaucer: As they have lately been compar'd with the best manuscripts, and several things added, never before in print. London: George Bishop. STC 5077, 5078, 5079, 5080, 5081, Wing C3736.

Spurgeon, Caroline F. E. 1914-1925. Five Hundred Years of Chaucer Criticism and Allusion 1357-1900, 7 Vols. London: Kegan Paul, Trench, Trubner for the Chaucer Society.

Stow, John, ed. 1561. The Woorkes of Geffrey Chaucer newlie printed, with diuers addicions, which were never in printed before. London: John Kyngston. (STC 5075, 5076, 5076.3.

Thynne, William, ed. 1532. The Workes of Geoffrey Chaucer newly printed, with dyuers workes whiche were neuer in print before. London: Thomas Godfray. STC 5068, 5069, 5070, 5071, 5072, 5073, 5074. 
Tyrw hitt, Thomas, ed. 1778. The Canterbury Tales of Chaucer, to which are added, an essay upon his language and versification; an introductory discourse; and notes. first ed. London: Thomas Payne. STC T76319.

Tyrwhitт, Thomas, ed. 1798. The Canterbury Tales of Chaucer, second ed. Oxford: Clarendon Press.

Tyrwhitt, Thomas. 1775-8. "An Account of the Works of Chaucer to which this Glossary is adapted; and of those other Pieces which have been improperly intermixed with his in the Editions". The Canterbury Tales of Geoffrey Chaucer, edited by Thomas Tyrwhitr, vii-xxiii. London: Thomas Payne.

Tyrwhitt, Thomas. 1783. Gentleman's Magazine. 53: 461-62.

URRY, John, ed. 1721. The Works of Geoffrey Chaucer, Compared with the Former Editions, and Many valuable MSS, out of which, Three Tales are added which were never before printed. London: Bernard Lintot. STC T106027.

Wilcockson, Colin. 1987. "The Book of the Duchess". The Riverside Chaucer, edited by Larry D. Benson. Oxford: Oxford University Press.

Wood, Anthony. 1691-2. Athenae Oxonienses: The History of the Writers of the University of Oxford, from the Year of our Lord 1500 to the end of 1640. London: Thomas Bennet. 